\title{
ПОДТВЕРЖДАЕМОСТЬ СЕЙСМИЧЕСКИХ ПРОГНОЗОВ БУРЕНИЕМ ЭКСПЛУАТАЦИОННЫХ СКВАЖИН (РАЗВЕНЧАНИЕ МИФОВ О ВОЗМОЖНОСТЯХ МОГТ)
}

Прежкенчев A.A. * Скачек К.Г.**

\author{
(* ООО «КогальиННПНнефть»; ** - ТПП «Когальмнефтегаз»)
}

В институте ООО «КогалымНИПИнефть» проводится мониторинг в пределах разбуриваемьг кустов. Загружаются: сейсмический куб $3 Д$, даннье по скважинам (обычно от 80 до 250 скважин), которые используются для обучения (для выбора сейсмических атрибутов и поиска зависимостей), и через 2 недели получаем проверку наших прогнозов в виде последующей скважины. Вначале когда пытались найти зависимость в пределах всего анализируемого куба, подтверждаемость прогнозов была достаточно низкой. Пришлось тризнать, пто на сейсмические атрибуты влияет множество параметров геологической среды, которые при живом мониторинге (в течения 2-3 суток) выявить не реально, практика жоказывает, что иногда и в течение несколькн месяцев однозначный ответ не находитеп.

При построении структурных карт по продуктивным пластам для выбора уровня ВНК используются заключения по ГКС, в большинстве случаев на разных участках оказываются разные уровни подошвы нефтенасыщенных пропластков (разные ВНК). На этом основании уже можно предполагать, что такие участки относятся к разным фациальным зонам. Сопоставление $c$ другими уровнями (с юрскими, доюрскими и клиноформными комплексами) показывает, что границы сейсмофаций (соответственно, и фаций) пространственно тяготеют к границам тектонических нарушений (а иногда и совпадают), к границам зон с аномальным разрезом баженовской свиты или к границам клиноформ, то есть, обусловлены условиями седиментации.

Достаточно часто даже в пределах одного куста ошибки колеблются от $-2 \mathrm{M}$ до $+18 \mathrm{M}$, а ниже в таблице №1 приведен пример, когда на юге куста ошибка составила $-3 \mathrm{M}$, а на севере достигла $22 \mathrm{M}$. Такой разброс ошибок (пропеллером) простым подъемом или опусканием структурной поверхности не исправить.

В таблище №2 приведен пример, когда в пределах куста, по сейсмическому прогнозу из перспективных был выброшен целый пласт, куст разбуривался на другой пласт и только поэтому данный пласт также будет разрабатываться. А сколько возможно случаев реальных пропусков?

При работе с проектами по ВСП (НВСП) мы попытались оценить влияние зон многолетнемерзлых пород (с большими интервальными скоростями)

Таб.лища №2 и зон растепления (с очень низкими интервальньгии скоростями). Оказалось, что зоны растепления в большей мере искажают истинный структурный план, чем ММП. А при обработке большинство обработчиков учитывает только влияние МMI, что автоматически приводит к гораздо худшим последствиям, чем если бы они вообще не вводили поправок за длиннопериодную статику. В настоящее время активно разбуриваются краевые части место-

Таблица №1 рогнозов в северной части Кочевского месторождения

\begin{tabular}{|c|c|c|c|c|}
\hline $\begin{array}{l}\mathrm{dh} \\
\text { оmибка }\end{array}$ & $\begin{array}{l}\text { насыщен } \\
\text { по сейсмике }\end{array}$ & $\begin{array}{l}\text { насыщен } \\
\text { по скважине }\end{array}$ & $\begin{array}{l}\mathrm{h} \text { эक } \\
\text { БC10 } 2+3\end{array}$ & $\begin{array}{l}\text { h эф неф. } \\
\text { БС10 } 2+3\end{array}$ \\
\hline 14.5 & $\mathrm{H}+\mathrm{B}$ & $\mathrm{H}+\mathrm{B}$ & 21.8 & 6.6 \\
\hline 19.5 & $\mathrm{H}+\mathrm{B}$ & $\mathrm{H}+\mathrm{B}$ & 18.6 & 3.8 \\
\hline 22.1 & $\mathrm{H}$ & $\mathrm{H}+\mathrm{B}$ & 17.2 & 7.8 \\
\hline 17.8 & H & $\mathrm{H}+\mathrm{B}$ & 23,4 & 6,2 \\
\hline 7.7 & H & $\mathrm{H}+\mathrm{B}$ & 16,4 & 5,8 \\
\hline 4.6 & $\mathrm{H}$ & $\mathrm{H}+\mathrm{B}$ & 11.8 & 4,0 \\
\hline 21.3 & $\mathrm{H}+\mathrm{B}$ & $\mathrm{H}+\mathrm{B}$ & 21.4 & 112 \\
\hline 4,3 & $\mathrm{H}$ & $\mathrm{H}+\mathrm{B}$ & 12,6 & 2.0 \\
\hline$-3,0$ & Bода & $\mathrm{H}+\mathrm{B}$ & 18.6 & 28 \\
\hline
\end{tabular}

рождений, нефтяники пытаются разрабатывать даже такие участки, где нефтенасышенная толщина составляет всего 1-3м (в зоне ВНК), поэтому даже небольшие ошибки в структурном плане «сливаются» в виде десятков миллионов рублей.

При прогнозировании зон глинизации (коплекторов) в настоящее время действуем по следующей схеме: по временғым разрезам или по картам динамических атрибутов, с учетом данных по сквакуст 92 Тевлинско-Русскинского месторождения

\begin{tabular}{|c|c|c|c|c|c|c|c|c|c|}
\hline & \multicolumn{3}{|c|}{ данные по скважынау } & \multicolumn{3}{|c|}{ прогнозные оценки по } & \multirow[b]{2}{*}{ ошибка } & \multirow[b]{2}{*}{ опибка } \\
\hline KYCT & CKB & a.o & Нэф. & Нэф & a.o & $\mathrm{H}$ & Нэф & & \\
\hline 92 & 7932 & - & 1 & 1 & -2409 & 0 & 0 & 216 & 1 \\
\hline 92 & 7909 & -2391 & 122 & 122 & нет & 0 & 0 & & 122 \\
\hline 92 & 6464 & $=$ & 4,8 & 4.8 & HeT & 0 & 0 & & 48 \\
\hline 92 & 7910 & - & 12,8 & 12.8 & -2405 & 0 & 0 & 21.2 & 128 \\
\hline 92 & 7887 & - & 12,6 & 12.6 & HeT & 0 & 0 & & 126 \\
\hline 92 & 7888 & - & 7.8 & 7.8 & HeT & 0 & 0 & & 28 \\
\hline 100 & 9354 & - & 10 & 10 & -2356 & 14 & 14 & -9 & -4 \\
\hline
\end{tabular}
жинам, делим исследуемый участок, с определенной долей условности, на сейсмофациальные зоны и затем в пределах каждой такой зоны определяем перспективность исследуемого пласта. Такой подход позволил достигнуть достаточно высокой подтверждаемости наших прогнозов, пока процент удачи более $80 \%$. Еесли бы мы руководствовались Методическими рекомендациями ЦГЭ 2006 года, то примерно в $40 \%$ случаев нам пришлось бы говорить, что никакого прогноза дать не можем (участки, не отвечающие типовому уровню точности, из прогноза рекомендовано исключать), и даже при удате в $80 \%$ (на оставшиеся 60\%), реальный удачный прогноз получился бы только в $50 \%$ случаев. Таким образом, можно констатировать, что глобальный подход к интерпретации сейсмических данныг оправдан только на разведочном этапе. 